plasma concentrations; to do so would obviously be illuminating.

The delayed response to oral therapy is more difficult to explain. The drug was taken about three-quarters of an hour after breakfast in both the normal subjects and patients and the nature of the meal was similar in the two groups. A similar time course of effect could therefore have been expected. As the response to intravenous frusemide was as prompt in the patients as in the normal subjects a renal cause for the delay cannot be postulated. A decreased rate of absorption of the drug from the gastrointestinal tract is possible, perhaps caused by a reduction in gastrointestinal motility. Decreased gastric emptying produced by propantheline has been shown to delay paracetamol absorption (Nimmo et al., 1973), and it is known from animal experiments (Woodbury, 1969) that spontaneous activity in gastrointestinal smooth muscle is greatly diminished by phenytoin.

Anticonvulsant drugs are potent hepatic enzyme inducers (Richens, 1974) and cause a considerably shortened plasma half life of many drugs. Increased metabolism on "first pass" through the liver can considerably reduce the plasma concentration of a drug which is metabolized by liver enzymes. Frusemide, however, is metabolized to a small degree (Lasix: International Furosemide Symposium, 1964) and therefore it is unlikely that enzyme induction would explain the abnormal response seen in this study.
The patients' urine volumes were higher than the normal subjects' after placebo treatment (figs. 1-3). Whether drinking habits account for this or whether phenytoin inhibits antidiuretic hormone release when used chronically, as has been shown after acute administration (Fichman et al., 1973), is uncertain. Obviously the diuretic effect of frusemide might be modified by such an action.

I thank Dr. Alan Richens for his advice and constant help, especially in writing this paper; Dr. John Laidlaw for his constant support and encouragement; the members of the staff at Chalfont Centre for Epilepsy for their co-operation; Dr. Peter R. Read of Hoech t Pharmaceuticals, for supplying the drugs etc. and for his help; and Mrs. J. Ashley and Mrs. R. Fazakerley for secretarial help.

\section{References}

Fichman, M. P., Kleeman, C. R., and Bethune, J. E. (1973). Archives of Neurology, 22, 45.

Lasix: International Furosemide Symposium (1964). Frankfurt, Hoechst.

Koch, A., et al. (1962). Physiologist, 5, 168

Nimmo, J., et al. (1973). British Medical fournal, 1, 587.

Richens, A. (1974). British Fournal of Clinical Pharmacology. In press.

Woodbury, D. M. (1969). In Basic Mechanism of Epilepsies, ed. H. H. Jasper, A. A. Ward, and A. Pope, p. 647. London, Churchill.

\title{
Familial Trends in Low Birth Weight
}

\author{
FRANK JOHNSTONE, LESLEY INGLIS
}

British Medical fournal, 1974, 3, 659-661

\section{Summary}

The reproductive performance of sisters and sisters-inlaw of 185 women who had delivered "light-for-dates" and "premature expulsion" low birth weight infants was studied. Percentile birth weights were compared taking into account length of gestation, fetal sex, and the height, weight, parity, and smoking habits of the mother. Sisters of women who had delivered light-for-dates babies had lighter babies than the general population, their sistersin-law, or the sisters of women in the premature expulsion group. These other groups, however, had the expected distribution of percentile birth weights. Data on familial trends in smoking habits and unknown gestation are also presented. The results are consistent with the theory that the mother's own intrauterine experience affects her reproductive performance but could also be explained by shared family learning experience of as yet unidentified microsocial factors related to pregnancy performance.

\section{Introduction}

In recent years much attention has been paid to the recognition and management of infants with intrauterine growth retardation. These infants are associated with a significant increase

\footnotetext{
Department of Obstetrics and Gynaecology, Aberdeen Maternity Hospital, Aberdeen AB9 2ZD
}

FRANK JOHNSTONE, M.B., M.R.c.o.G., Registrar

Centre for Social Studies, Aberdeen

LESLEY INGLIS, M.A., Research Fellow in perinatal mortality (Gruenwald, 1969) and are at an increased risk in the neonatal period (Bard, 1970). When compared with control groups at follow-up examination they also seem to be smaller and have poorer physical development (Van den Berg and Yerushalmy, 1966; Tarumoto, 1966; Fitzhardinge and Steven, 1972 a), an increased incidence of speech defects, a poorer school performance (Fitzhardinge and Steven, 1972 b), and possibly suffer from intellectual impairment (Wiener, 1970). Growth retardation seems more commonly to be due to failure of uteroplacental support rather than low growth potential of the fetus, and the aetiology of this is not clearly understood.

One explanation suggested by Ounsted and Ounsted (1966) is that intrauterine growth is determined by a maternal regulating factor, and they emphasized that mothers of "light-fordates" infants tend to have no large babies and seem regularly to constrain the intrauterine growth of their young. Furthermore, they suggested that the mother's own intrauterine experence affected her subsequent reproductive performance (Ounsted and Ounsted, 1968)

This study was devised to compare the reproductive performance of sisters and sisters-in-law (brothers' wives) of women who had produced infants of low birth weight on the basis that their sisters to a certain extent had shared their intrauterine experience, while their sisters-in-law, though from similar social class, had not.

\section{Methods}

The data were collected in Aberdeen, which offers particular advantages for this type of study. The population is socially varied but ethnically homogeneous and until recently migration in and out of the city has been low. Since 1948 well over $80 \%$ of all births have taken place in the one teaching maternity hospital, and centralized comprehensive records of all pregnancies are available. During this time also particular attention has been paid to the collection and recording of data. 
Every patient who had a low birth weight baby (defined as any baby born after 28 weeks gestation and weighing under 2,500 g) in Aberdeen during a 16-month period was interviewed and asked for details of the births of babies born to her siblings. The sister or brother's wife was then identified in the hospital records and the following information recorded for each pregnancy: maternal age, height, weight at 20 weeks, smoking habits, pregnancy complications, and the birth weight, gestation, and sex of the infant. In this way 242 index cases with siblings were identified.

Gestation ages are recorded in the Aberdeen notes as certain, uncertain (where a "best estimate" of gestational age is given), or not known.

For each pregnancy a percentile birth weight, corrected for gestation, parity, fetal sex, and maternal height and weight at 20 weeks gestation was calculated using the tables of Thomson et al. (1968). All index babies weighed $2,500 \mathrm{~g}$ or below. "Lightfor-dates" infants were defined as those born after the 37th completed week of pregnancy and weighing less than the 10th percentile after correction for fetal sex, gestation, and maternal parity, height, and weight. "Premature expulsion" infants of normal intrauterine growth but short gestation were defined as those born before the 37th completed week of pregnancy and weighing more than the 10th percentile after correction for gestation, sex, and maternal parity, height, and weight. Where an index pregnancy was of unknown gestation but the index mother had had another low birth weight baby of known gestation she was allocated to the group corresponding to that pregnancy. Twin pregnancies were excluded.

Statistical comparisons were made using the $\chi^{2}$ test with Yates's correction where indicated.

\section{Results}

Of the 242 index mothers 185 fitted into either the light-fordates or premature expulsion categories. The others did not because either the index baby was born before 37 weeks but was lighter than the 10 th percentile ( 38 cases) or it was born after 37 weeks but was heavier than the 10th percentile (seven cases) or it was of completely unknown gestation (12 cases). The percentile birth weights, corrected for maternal height and weight, parity, sex, and gestation, of their siblings' infants are shown in table 1. The figures were analysed by $\chi^{2}$ test with grouping into three categories: under the 25 th percentile, from the 25 th to the 75 th percentile, and above the 75 th percentile. The sisters of the index mothers of light-for-dates babies had lighter babies than the general population $(P<0.001)$, their sistersin-law $(P<0.005)$, and the sisters $(P<0.001)$ and sisters-in-law
$(P<0.05)$ of the mothers of premature-expulsion babies. There was the expected distribution of percentile birth weights in the case of the sisters-in-law of the mothers of light-for-dates babies $(P>0.95)$ and the sisters of the mothers of premature expulsion babies $(\mathrm{P}<0.30>0.20)$ though the sisters-in-law of the latter mothers seemed to have lighter babies than the general population $(P<0.05)$. There was no significant difference in social class between groups (Office of Population Censuses and Surveys, 1970), but there was a high proportion of women from lower social classes in all categories.

Though smoking was more common in sisters of the mothers of light-for-dates children than in the other groups this did not reach statistical significance and was not likely to be the reason for the greater proportion of lighter babies in this group.

In only a few cases were data about smoking recorded, but when those patients who were known not to smoke were studied the sisters of the mothers of light-for-dates babies group still had lighter babies than the other groups combined $(P<0.001$ and this was also true of those patients who were known to smoke $(P<0.02$; table II).

Sisters of index mothers who had premature-expulsion infants had a higher proportion of babies born before 38 weeks than the sisters-in-law or the relatives of the light-for-dates group (table III). When these cases were compared with the other three groups combined this attained probable statistical significance at the 5\% level.

Two other interesting observations were made from the data. The index cases were divided into two groups according to

TABLE III-Number of Babies born before and after 38 Weeks to Sisters and Sisters-in-law of Index Mothers with Light-for-dates and Premature-expulsion Babies

\begin{tabular}{|c|c|c|c|}
\hline Index Case & Relative & $\begin{array}{c}\text { Babies born } \\
\text { before } 38 \text { Weeks }\end{array}$ & $\begin{array}{l}\text { Babies born } \\
\text { after } 38 \text { Weeks }\end{array}$ \\
\hline $\left.\begin{array}{l}\text { Light-for-dates } \\
\text { Premature expulsion }\end{array}\right\}$ & $\begin{array}{l}\text { Sisters } \\
\text { Sisters-in-law } \\
\text { Sisters } \\
\text { Sisters-in-law }\end{array}$ & $\begin{array}{l}19(10 \%) \\
8(8 \%) \\
33(16 \%) \\
12(9 \%)\end{array}$ & $\begin{array}{r}174 \\
94 \\
177 \\
120\end{array}$ \\
\hline
\end{tabular}

TAVLE IV-Frequency of Unknown Gestation in Sisters and Sisters-in-law according to whether Index Mother had had any Pregnancy of Unknown or Uncertain Gestation

\begin{tabular}{|c|c|c|c|}
\hline Index Case & Relative & $\begin{array}{l}\text { No }(\%) \text { of } \\
\text { Pregnancies } \\
\text { of Unknown } \\
\text { Gestation }\end{array}$ & $\begin{array}{c}\text { No. of } \\
\text { Pregnancies } \\
\text { of Known } \\
\text { Gestation }\end{array}$ \\
\hline $\begin{array}{l}\text { Any pregnancy of } \\
\text { unknown or uncertain } \\
\text { gestation }\end{array}$ & $\begin{array}{l}\text { Sisters-in-law } \\
\text { Sisters }\end{array}$ & $\begin{array}{l}10(9) \\
31(19)\end{array}$ & $\begin{array}{l}102 \\
135\end{array}$ \\
\hline $\begin{array}{l}\text { All pregnancies of } \\
\text { known gestation }\end{array}$ & $\begin{array}{l}\text { Sisters } \\
\text { Sisters-in-law }\end{array}$ & $\begin{array}{l}40(10) \\
35(14)\end{array}$ & $\begin{array}{l}359 \\
221\end{array}$ \\
\hline
\end{tabular}

TABLE I-Numbers of Babies of Sisters and Sisters-in-Law of Index Mothers with Light-for-dates and Premature-expulsion Babies in Percentile Birth Weight Groups

\begin{tabular}{|c|c|c|c|c|c|c|c|}
\hline \multirow{2}{*}{ Index Case } & \multirow{2}{*}{ Relative } & \multicolumn{6}{|c|}{ Percentile Birth Weights } \\
\hline & & $<10$ & -25 & -75 & -90 & $>90$ & Total \\
\hline $\begin{array}{l}\text { Light-for-dates } \\
\text { Premature expulsion }\end{array}$ & $\begin{array}{l}\text { Sisters } \\
\text { Sisters-in-law } \\
\text { Sisters } \\
\text { Sisters-in-law }\end{array}$ & $\begin{array}{c}26(14 \%) \\
9(9 \%) \\
19(9 \%) \\
13(10 \%)\end{array}$ & $\begin{array}{l}54(28 \%) \\
16(15 \%) \\
24(12 \%) \\
23(12 \%)\end{array}$ & $\begin{array}{r}86(45 \%) \\
53(51 \%) \\
112(55 \%) \\
73(57 \%)\end{array}$ & $\begin{array}{l}13(7 \%) \\
13(13 \%) \\
29(14 \%) \\
13(10 \%)\end{array}$ & $\begin{array}{c}12(6 \%) \\
12(12 \%) \\
18(9 \%) \\
6(5 \%)\end{array}$ & $\begin{array}{l}191(100 \%) \\
103(100 \%) \\
202(100 \%) \\
128(100 \%)\end{array}$ \\
\hline
\end{tabular}

TABLE II-Numbers of Babies of Non-smoking and Smoking Sisters and Sister-in-law of Index Mothers with Light-for-dates and Premature-expulsion Babies in Percentile Birth Weight Groups

\begin{tabular}{|c|c|c|c|c|c|c|c|}
\hline \multirow{2}{*}{ Index Case } & \multirow{2}{*}{ Relative } & \multicolumn{6}{|c|}{ Percentile Birth Weights } \\
\hline & & $<10$ & -25 & -75 & -90 & $>90$ & Total \\
\hline \multicolumn{8}{|c|}{ Non-smoking Relatives } \\
\hline $\begin{array}{l}\text { Light-for-dates } \\
\text { Premature expulsion }\end{array}$ & $\begin{array}{l}\text { Sisters } \\
\text { Sisters-in-law } \\
\text { Sisters } \\
\text { Sisters-in-law }\end{array}$ & $\begin{array}{l}8(19 \%) \\
2(7 \%) \\
2(4 \%) \\
1(6 \%)\end{array}$ & $\begin{array}{r}11(26 \%) \\
3(10 \%) \\
5(10 \%) \\
0\end{array}$ & $\begin{array}{l}19(45 \%) \\
19(63 \%) \\
29(58 \%) \\
11(65 \%)\end{array}$ & $\begin{array}{l}2(5 \%) \\
4(13 \%) \\
9(18 \%) \\
2(12 \%)\end{array}$ & $\begin{array}{l}2(5 \%) \\
2(7 \%) \\
5(10 \%) \\
3(18 \%)\end{array}$ & $\begin{array}{l}42(100 \%) \\
30(100 \%) \\
50(100 \%) \\
17(100 \%)\end{array}$ \\
\hline \multicolumn{8}{|c|}{ Smoking Relatives } \\
\hline $\begin{array}{l}\text { Light-for-dates } \\
\text { Premature expulsion }\end{array}$ & $\begin{array}{l}\text { Sisters } \\
\text { Sisters-in-law } \\
\text { Sisters } \\
\text { Sisters-in-law }\end{array}$ & $\begin{array}{c}13(19 \%) \\
3(16 \%) \\
4(7 \%) \\
3(13 \%)\end{array}$ & $\begin{array}{r}21(30 \%) \\
4(21 \%) \\
7(13 \%) \\
6(25 \%)\end{array}$ & $\begin{array}{l}27(39 \%) \\
8(42 \%) \\
38(68 \%) \\
14(58 \%)\end{array}$ & $\begin{array}{l}2(3 \%) \\
3(16 \%) \\
5(9 \%) \\
1(4 \%)\end{array}$ & $\begin{array}{l}6(9 \%) \\
1(5 \%) \\
2(4 \%) \\
0\end{array}$ & $\begin{array}{l}69(100 \%) \\
19(100 \%) \\
56(100 \%) \\
24(100 \%)\end{array}$ \\
\hline
\end{tabular}


whether or not the index mother had had any pregnancy of unknown or uncertain gestation and into another two groups according to whether or not the mother case smoked. The sisters and sisters-in-law in each group were compared, firstly, with each pregnancy being recorded as either of known or unknown gestation; and, secondly, according to smoking habit.

The sisters of the index cases with any pregnancy of unknown or uncertain gestation had significantly more pregnancies of completely unknown gestation than their sisters-in-law $(P<0.05)$ or the sisters of the index cases whose pregnancies were all of known gestation $(P<0.01$; table IV).

Where the index mother was known to be a smoker 40 out of the 71 sisters whose smoking habits were known also smoked $(56 \%)$ whereas where the index mother was known not to smoke only seven out of 33 sisters whose habits were known smoked $(21 \%)$. The difference was statistically significant $(P<0.01)$.

\section{Discussion}

Ounsted and Ounsted (1968) proposed that fetal growth rate might be influenced by two main variables, the antigenic dissimilarity between mother and fetus (Billington, 1964) and the set of the maternal regulator. On the basis of pedigree studies of crude birth weights they suggested that the mother's own intrauterine experience affected her subsequent reproductive performance. Ounsted (1971) stated that "though the mechanism itself is probably specified genomically pedigree data indicate that the actual set of the maternal regulator may be determined by the degree of constraint imposed on the mother when she herself was a fetus."

In this study we found that the sisters of women who had children with reduced intrauterine growth, who to a certain extent have a comparable intrauterine experience, also tended to have children with relatively reduced intrauterine growth and that this seemed to be independent of associations such as preponderance of female children, short gestation, high prevalence of primiparity, low maternal height and weight, or smoking habits. This was not true of their brothers' wives, who as far as social class was concerned represented a control group but who did not have a comparable intrauterine experience, nor was it true of the sisters of women who had babies of normal intrauterine growth but who delivered prematurely. In both these cases, after correction for sex, parity, gestation, and maternal height and weight, the distribution of percentile birth weights was the same as in the general Aberdeen population. On the other hand, sisters of women with low birth weight babies due to premature expulsion seemed to have a slightly higher proportion of babies born before the end of the 37th week than the other groups.
As with smoking unknown or uncertain gestation was not randomly distributed but was significantly more common in the sisters of index mothers who had had a pregnancy of uncertain gestation than in the sisters-in-law or the sisters of index mothers whose pregnancies were all of known gestation. This might have been partly because of irregular menstrual cycles but was probably mainly due to "forgotten dates," possibly reflecting a different attitude to menstruation as a result of shared learning experience in the family environment. Beazley and Underhill (1971) showed that the perinatal mortality rate in patients with unknown dates was four to five times greater than in patients with known dates.

In conclusion, our findings do offer support for the Ounsted theory. There can be no doubt that sisters of women who have produced a light-for-date baby tend to have babies with relatively reduced intrauterine growth. This tendency is independent of social class, maternal size, or smoking habits. It is unlikely to be a genetic mechanism as the effect is not transmitted through the male siblings. Nevertheless, this tendency cannot necessarily be attributed to the similar intrauterine experience. Just as sisters of women who smoke or who have unsure dates also tend to smoke or have unsure dates so other variables possibly relevant to fetal growth, such as dietary habit or other as yet unidentified microsocial factors, may also occur more commonly in sisters as a result of a shared learning experience in the family. There is, therefore, a familial component to growth retardation, and it is operative on the female side but not the male side.

We thank Professor I. MacGillivray for his advice about the study and his help in the preparation of the manuscript.

Requests for reprints should be sent to Dr. Frank Johnstone.

\section{References}

Bard, H. (1970). Clinical Obstetrics and Gynecology, 13, 511.

Beazley, J. M., and Underhill, R. A. (1971). Nursing Times, 67, 1414.

Billington, W. D. (1964). Nature, 202, 317.

Fitzhardinge, P. M., and Steven, E. M. (1972 a). Pediatrics, 49, 671.

Fitzhardinge, P. M., and Steven, E. M. (1972 b). Pediatrics, 50, 50.

Gruenwald, $P$. (1969). In Perinatal Problems: The second report of the 1958 British Perinatal Survey, ed. N. R. Butler and E. D. Alberman. EdinBritish Perinatal Sur
burgh, Livingstone.

Ounsted, M., and Ounsted, C. (1966). Nature, 212, 995.

Ounsted, M., and Ounsted, C. (1966). Nature, 212, 995.

Ounsted, M., (1971). Development Medicine and Child Neurology, 13, 524

Oufice of Population Censuses and Surveys (1970). Classification of Occupations. London, H.M.S.O.

Tarumoto, S. (1966). Hiroshima fournal of Medical Sciences, 15, 239.

Thomson, A. M., Billewicz, W. Z., and Hytten, F. E. (1968). fournal of Obstetrics and Gynaecology of the British Commonwealth, 75, 903 .

Van den Berg, B. J., and Yerushalmy, J. (1966). Fournal of Pediatrics, 69, 531. Wiener, G. (1970). Fournal of Pediatrics, 76, 694. 